\title{
Conceição Evaristo
}

\section{Poemas}

\section{INQUISIÇÃO}

Ao poeta que nos nega

Enquanto a inquisição

Interroga

a minha existência

e nega o negrume

do meu corpo-letra

na semântica

da minha escrita,

prossigo.

Assunto não mais

o assunto

dessas vagas e dissentidas

falas.

Prossigo e persigo

outras falas,

aquelas ainda úmidas,

vozes afogadas,

da viagem negreira.

E apesar

de minha fala hoje

desnudar-se no cálido

e esperançoso sol

de terras brasis, onde nasci,

o gesto de meu corpo-escrita

Levanta em suas lembranças

Esmaecidas imagens

de um útero primeiro. 
Por isso prossigo.

Persigo acalentando

nessa escrevivência

não a efígie de brancos brasões,

sim o secular senso de invisíveis

e negros queloides, selo originário,

de um perdido

e sempre reinventado clã. 


\section{Carolina na hora da estrela}

No meio da noite

Carolina corta a hora da estrela.

Nos laços de sua família um nó

- a fome.

José Carlos masca chicletes.

No aniversário, Vera Eunice desiste

do par de sapatos,

quer um par de óculos escuros.

João José na via-crúcis do corpo,

um sopro de vida no instante-quase

a extinguir seus jovens dias.

E lá se vai Carolina

com os olhos fundos,

macabeando todas as dores do mundo...

Na hora da estrela, Clarice nem sabe

que uma mulher cata letras e escreve

"De dia tenho sono e de noite poesia" 


\section{Clarice no quarto de despejo}

No meio do dia

Clarice entreabre o quarto de despejo pela fresta percebe uma mulher.

Onde estiveste à noite, Carolina?

Macabeando minhas agonias, Clarice.

Um amargor pra além da fome e do frio,

Da bica e da boca em sua secura.

De mim, escrevo não só a penúria do pão, cravo no lixo da vida, o desespero, uma gastura de não caber no peito, e nem no papel.

Mas, ninguém me lê, Clarice,

Para além do resto.

Ninguém decifra em mim

a única escassez da qual não padeço,

- a solidão -

E ajustando o seu par de luvas claríssimas

Clarice futuca um imaginário lixo

e pensa para Carolina:

- a casa poderia ser ao menos de alvenaria -

E anseia ser Bitita inventando um diário:

páginas de jejum e de saciedade sobejam,

a fome nem em pedaços

alimenta a escrita clariciana.

Clarice no quarto de despejo

lê a outra, lê Carolina, a que na cópia das palavras, faz de si a própria inventiva.

Clarice lê :

- despejo e desejos - 


\section{Só de sol a minha casa}

\section{A Adélia Prado, com licença, que também sou mineira}

Durante muito tempo, também tive um sol a inundar a nossa casa inteira, tal a pequenez do cômodo.

Pelas fendas do machucado zinco, folhas escaldantes de nosso teto, invasivos raios confrontavam pontos de mil quentura.

E Jorrantes jatos de fogo Abrasavam o vazio de um estorricado chão .

Em dias de maior ardência, minha mãe alquebrava seu milenar e profundo cansaço no recorte disforme de um buraco - janela sem janela acontecido no centro de uma frágil parede.

(rota de fuga de uma presa a inventar a extensão de um prado)

Eu não sei por que, ela olhava o tempo e nos chamava para perscrutar em que lugar morava a esperança. Olhávamos. Salvou-nos a obediência.

Janeiro, 2014 


\section{A EMPREGADA E O POETA}

Na suspeição de que a empregada envenenaria o poeta anteciparam as dores dos livros.

Folhas mortas despencariam dos troncos, lombadas folheadas em ouro, tesouro do poeta, que a mesma serviçal eficiente e justa cuidava em sua obra.

A empregada envenenaria o poeta, um mofo podre avolumaria De cada letra morta. E a biblioteca manuseada pela mente assassina esperaria uma nova edição de um debochado cordel, que cantaria a história do poeta e do bife envenenado, trazendo o verso final:

" o peixe morre é pela boca."

Todos suspeitariam, condolências antecipadas surgiriam em prosa e verso.

Entretanto suspeição alguma ouviu e leu a história da empregada. Ela jamais assassinaria o poeta.

Quando o bife passou quase amargo e cru, foi porque o tempo logrou as tarefas de Raimunda. O não e o mal feito da empregada eram gastos às escondidas em leituras do tesouro que não lhe pertencia.

No entanto ela sabia, mesmo antes do poeta, 
que rima era só rima.

E em meio às lacrimejantes cebolas

misturadas às dores apimentadas

nos olhos do mundo,

Raimunda entre vassouras, rodos,

panelas e pó desinventava de si

as dores inventadas pelo poeta.

$25 / 07 / 2012$

Conceição Evaristo (1946) vive no Rio de Janeiro. É doutora em Literatura Comparada e autora de poemas, contos e romances. Também escreve crítica. Publicou, entre outros livros, os romances Ponciá Vicêncio (2003) e Becos da memória (2006), além do livro de contos Insubmissas lágrimas de mulheres (2011). 